\title{
Penggarapan Ragam Hias dengan Teknik Gradasi pada Pembelajaran Seni Rupa
}

\author{
Muhsin Ilhaq ${ }^{1)}$, Rio Eka Putra ${ }^{2)}$ \\ ${ }^{12)}$ Program Studi Sendratsik,Universitas PGRI Palembang \\ Jl. A. Yani Lrg. Gotong Royong 9/10 Ulu Palembang \\ Email : ilhaque@gmail.com ${ }^{1)}$, rioep@gmail.com ${ }^{2}$
}

\begin{abstract}
Learning resources are basically available in the surrounding environment. A learning approach based on the surrounding environment will provide a more interesting learning experience and can stimulate positive motivation. In order for the learning process to be carried out well, enrichment of the learning resources needs to be done. This study aims to get an overview of learning methods based on the surrounding environment by utilizing decorative ornaments at the Palembang Great Mosque as a learning resource. Furthermore, through this research researchers are expected to get a formulation of the use of decorative ornaments at the Palembang Great Mosque as a source of learning. Aside from being a form of support for the government in the context of inheritance and maintaining physical cultural products in the form of written documentation. It is very rare to find art textbooks, especially about decoration. In fact, the author has not yet found a textbook specifically discussing the various decorations in Palembang, so this research needs to be done. The author is of the opinion that, the use of ornamental diversity at the Palembang Grand Mosque as a source of learning art knowledge can be done through two methods namely, observing forms of ornamentation directly in the field or through enriching learning resources.
\end{abstract}

Keywords : Learning Resources, Decorative Ornament, visual arts learning

\begin{abstract}
ABSTRAK
Sumber belajar pada dasarnya sudah tersedia di lingkungan sekitar. Pendekatan belajar berbasis pada lingkungan sekitar akan memberikan pengalaman belajar yang lebih menarik dan dapat merangsang motivasi positif. Agar proses belajar terlaksana dengan baik, maka pengayaan sumber belajar perlu dilakukan. Penelitian ini bertujuan untuk mendapatkan gambaran metode pembelajaran berbasis lingkungan sekitar dengan memanfaatkan ragam hias pada mesjid Agung Palembang sebagai sumber belajar. Selanjutnya, melalui penelitian ini diharapkan peneliti mendapatkan suatu formulasi pemanfaatan ragam hias pada Mesjid Agung Palembang sebagai sumber belajar. Di samping sebagai bentuk dukungan terhadap pemerintah dalam rangka pewarisan dan menjaga produk budaya fisik berupa dokumentasi tertulis. Sangat jarang ditemukan buku teks seni rupa, terutama tentang ragam hias. Faktanya, penulis belum menemukan buku teks secara khusus membahas ragam hias yang ada di Palembang, sehingga dengan demikian penelitian ini perlu dilakukan. Penulis berpendapat bahwa, Pemanfaatan ragam hias pada Mesjid Agung Palembang sebagai sumber belajar pengetahuan seni rupa dapat dilakukan melalui dua metode yakni, pengamatan bentuk ragam hias secara langsung di lapangan maupun melalui pengayaan sumber belajar.
\end{abstract}

Kata kunci : Sumber Belajar, Ragam Hias, Pembelajaran seni rupa 


\section{Pendahuluan}

\section{A. Latar Belakang}

Belajar dapat dilakukan dimanapun dan kapan saja, tidak ada batasan tertentu dalam belajar. Aktivitas belajar pada dasarnya dipahami sebagai suatu proses mendapatkan pengalaman, ilmu pengetahuan, keterampilan dan sikap dalam rangka meningkatkan kualitas hidup. Dengan demikian, terjadinya perubahan tingkat pengetahuan dan tingkah laku seseorang bisa menjadi tolok ukur bahawa seseorang telah melakukan proses belajar.

Proses belajar merupakan suatu sistem yang terkait dengan berbagai komponen pendukung dan saling berintegrasi, antara lain adalah sumber belajar, yaitu segala sesuatu yang bisa dimanfaatkan dan terlibat dalam proses belajar. Seperti yang disebutkan oleh Rosyada dalam Arsyat (kata sambutan, 2014) bahwa peroses belajar tidak akan berjalan dengan baik tanpa pengayaan sumber-sumber belajar, yakni meliputi pesan, orang, bahan, alat, teknik dan lingkungan yang dapat berpengaruh terhadap proses dan hasil belajar.

Motivasi serta dorongan untuk melakukan terobosan kreatif terus dilakukan dan dikembangkan melalui pendekatan berfikir inovatif. Intensitas dengan sumber belajar dapat membuka peluang lebih luas dalam hal pemahaman dan pemaknaan terhadap proses belajar, maupun pemaknaan yang berbeda terhadap materi pelajaran yang dipelajari. Melalui pengayaan sumber belajar, kualitas interaksi dengan sumber belajar dapat ditingkatkan dan hasil belajar bisa dicapai dengan maksimal. Di samping itu, pengayaan sumber belajar berbasis lingkungan sekitar sangat bermanfaat untuk memantapkan pembelajaran, memungkinkan belajar menjadi lebih menarik dan kreatif.

Terkait dengan sumber belajar seni rupa, berbagai jenis sumber belajar sudah tersedia di lingkungan sekitar Sitepu (2014) membedakan sumber belajar berdasarkan pembuatannya yakni (1) sumber belajar yang direncanakan untuk kepentingan belajar dan (2) sumber belajar yang dibuat bukan untuk keperluan belajar tetapi dapat dimanfaatkan untuk keperluan belajar. Dengan demikian sangat memungkinkan pengayaan ragam hias pada mesjid Agung Palembang menjadi sumber belajar.

\section{B. Permasalahan}

Jarang sekali ditemukan buku teks seni rupa yang membahas ragam hias, terutama ragam hias lokal, dalam konteks ini adalah ragam hias Palembang. Seperti yang disebutkan oleh Mudana (2007) bahwa tidak banyak buku teoritis yang secara lugas membahas pengetahuan lokal dalam arti yang sebenarnya. Sementara lingkungan sekitar begitu banyak menyediakan sumber ide tulisan yang layak dikembangkan sebagai sumber belajar.

Bangunan Mesjid Agung yang monumental dengan segala atribut yang melingkupinya, banyak sekali materi belajar yang dapat dikembangkan. Merujuk pada penelitian sebelumnya (Ilhaq, 2016) ragam hias yang terdapat pada Mesjid Agung Palembang mengandung nilai budaya dan nilai sejarah serta nilai religius. Sebagai salah satu kekayaan budaya fisik (material cultur). Ragam hias pada Mesjid Agung Palembang layak dan patut dijadikan sebagai sumber belajar.

Pemanfaatan ragam hias pada Mesjid Agung Palembang sebagai sumber belajar seni rupa tentu saja akan memberikan pengalaman belajar yang lebih kongkrit, sehingga merangsang motivasi positif serta belajar akan menjadi lebih menarik.

Penelitian ini merupakan suatu usaha untuk mendapatkan gambaran pembelajaran pengetahuan seni rupa berbasis lingkungan sekitar. Pemanfaatan ragam hias pada masjid Agung Palembang sebagai materi ajar, melalui penelitian ini diharapkan suatu formulasi pembelajaran seni rupa yang efektif. Secara khusus, penelitian ini bertujuan untuk memberikan pemahaman kepada mahasiswa tentang penggarapan ragam hias dengan teknik gradasi.

\section{Metodologi}

Penelitian ini membahas tentang pemanfaatan sumber belajar berbasis lingkungan sekitar. Pelaksanaan penelitian dilakuakan dengan pelibatan mahasiswa secara langsung di mesjid Agung Palembang. Pengumpulan data penelitian dilakukan melalui observasi terlibat, dokumentasi dan studi pustaka. Data yang terkumpul dianalasis untuk mendapatkan rumusan pemanfaatan ragam hias sebagai sumber belajar.

Observasi terlibat di perlukan untuk memahami kemampuan awal serta karakter kelompok belajar, subjek penelitian adalah mahasiswa Program Studi Sendratasik semester IV Universitas PGRI Palembang pada mata kuliah pengetahuan seni rupa. Keanekaragaman karakteristik pemelajar dalam kelompok belajar yang sama menuntut perlunya pendekatan pembelajaran individual, masing-masing pemelajar belajar dengan gaya belajarnya sendiri agar sama-sama dapat mencapai tujuan pembelajaran (Sitepu, 2014: 45). Kemampuan mahasiswa yang kurang memadai, serta karakter hedonis dan serba instan sangat melekat dengan mahasiswa. Berdasarkan pengalaman mengajar, khususnya mata kuliah pengetahuan seni rupa dipandang tidak begitu penting oleh mahasiswa. Sebab, obsesi mahasiswa Sendratasik lebih tertarik pada seni pertunjukan sepeti drama, tari dan musik.

Perlu dilakukan identifikasi apakah karakteristik sumber belajar sesuai dengan tujuan yang diharapkan dalam kurikulum. Agar mendapatkan informasi yang akurat, langkah awal yang dilakukan adalah observasi terlibat seperti yang ditawarkan oleh Rohidi (2011) bahwa metode penelitian ini memungkinkan peneliti dapat berada dalam tingkat keterlibatan tertentu dalam hubungannya dengan pelaku yang diteliti.

Pengumpulan data dilakukan Dengan pendekatan iterdisiplin, menurut Rohidi (2011) menggunakan pendekatan interdisiplin, berbagai cara yang relevan dengan penelitian memungkinkan membuka peluangpeluang baru yang bermanfaat bagi pengembangan bidang seni dan pendidikan seni secara khusus. Data penelitian dihimpun langsung bersama-sama dengan 
mahasiswa, melakukan pengamatan ragam hias pada mesjid Agung Palembang.

Selain memanfaatkan data dokumentasi dari mahasiswa. Peneliti dan Tim juga melakukan Pengambilan data dokumentasi menggunakan kamera di mesjid Agung Palembang dan di ruang kelas saat mahasiswa melakukan proses kerja mulai dari persiapan alat dan bahan, pembuatan desain, penggarapan karya hingga finishing.

Pemanfaatan sumber lain yang mendukung seperti buku-buku, terutama yang diterbitkan oleh pemerintah setempat untuk memperkaya informasi terkait ragam hias, serta memanfaatkan jurnal maupun artikel ilmiah juga digunakan sebagai referensi mem-pertajam analisa tentang sumber belajar.

Mempelajari sumber-sumber dan bahan tertulis yang relevan dengan topik penelitian perlu dilakukan untuk mendapatkan kesesuaian teori dengan masalah yang diteliti. Seperti yang telah dijelaskan pada bagian sebelumnya, bahwa peroses belajar tidak akan berjalan dengan baik tanpa pengayaan sumber-sumber belajar. Kualitas interaksi dengan sumber belajar dapat ditingkatkan melalui pengayaan sumber belajar, sehingga pemahaman terhadap materi yang dipelajari akan terbuka lebih luas. Berikut literatur yang berkaitan dengan penelitian:

Sitepu (2014) menulis buku Pengembangan Sumber Belajar, buku ini sangat berguna sebagai rujukan utama penelitian ini, pada BAB 2 buku tersebut dirumuskan pengertian belajar menurut pandangan behaviourisme, kognitivisme dan konstruktivisme sebagai suatu usaha sadar, terencana dan sistematis dengan menggunakan metode tertentu untuk mengubah perilaku relatif menetap melalui interaksi dengan sumber belajar, selanjutnya ia berpendapat bahwa sumber belajar merupakan salah satu komponen dalam kegiatan belajar yang memungkinkan individu memperoleh pengetahuan, kemampuan, sikap, keyakinan, emosi dan perasaan. Sumber belajar memberikan pengalaman belajar, tanpa sumber belajar maka tidak mungkin dapat terlaksana proses belajar dengan baik. Bagian (sub) sumber belajar di tengah-tengah masyarakat membedakan sumber belajar berdasarkan pembuatannya yakni (1) sumber belajar yang direncanakan untuk kepentingan belajar dan (2) sumber belajar yang dibuat bukan untuk keperluan belajar tetapi dapat dimanfaatkan untuk keperluan belajar. Penjelasan disertai ilustrasi rumah ibadah, bahwa orang dapat belajar tata cara beribadah, belajar agama melalui khotbah, mempelajari fungsi dan bagian-bagian rumah ibadah mempelajari masyarakat sekitar melalui bangunan rumah ibadah. Sangat penting sebagai konsep dasar penelitian ini dan relevan dengan topik penelitian yakni ragam hias pada mesjid Agung Palembang sebagai sumber belajar.

Selanjutnya pada Bab 3 buku ini menjelaskan tentang berbagai sumber belajar dan pendekatan belajar berbasis aneka sumber kemudian delengkapi dengan rancangan pembelajaran. Sangat berguna sebagai panduan kerangka penelitian serta petunjuk untuk menghimpun data yang dibutuhkan untuk penelitian.
Abdullah (2012) menulis Jurnal dengan judul Pembelajaran Berbasis Pemanfaatan Sumber Belajar. Dalam jurnal ini Abdullah menjelaskan pentingnya intensitas dengan sumber belajar, kemudian pada bagian pembahasan, ia mengemukakan dengan sistematis berbagai pendapat pakar terkait dengan pengertian, ruang lingkup serta fungsi sumber belajar. Selanjutnya Abdullah berpendapat bahwa pemanfaatan sumber belajar yang bervariasi belum merata pada tenaga pengajar dan peserta didik, kemudian ia menyebutkan sebagian tenaga pengajar dan sebagaian besar peserta didik belum sepenuhnya memanfaatkan sumber belajar yang tersedia, menurut Abdullah hal tersebut terjadi disebabkan karena keterbatasan pengetahuan tentang sumber belajar, keterbatasan akses ke sumber belajar dan tidak tersedianya sumber belajar yang memadai. Tulisan ini tidak membahas objek material dari sumber belajar namun lebih pada pemanfaatan sumber belajar secara teoritis. Meskipun demikian, tulisan ini sangat berguna sebagai sumber referensi untuk mempertajam analisa terkait dengan sumber belajar.

Jurnal Seni Budaya Mudra (Volume 21 No. 2 September 2007) memuat tulisan dengan judul Pengetahuan Lokal Dalam Epistemologi Relasional: kajian filsafat kebudayaan di tulis oleh Mudana. Perpaduan Globalisasi dan Lokalisasi (Globalism dan Lokalism) melahirkan istilah "Glokalisasi" diperkenalkan oleh Mike Featherstone agaknya menjadi masukan yang sangat berharga dan dapat di aplikasikan dalam dunia pendidikan, terutama terkait dengan sumber belajar, bahwa materi ajar sebaiknya berangkat dari pengetahuan lokal (kearifan lokal). Mudana juga menyebutkan bahwa pengetahuan lokal ternyata memiliki nilai yang layak untuk dikembangkan, ia kemudian mencontohkan Tri Hita Karana yakni konsep keseimbangan dalam kebudayaan Bali. Terciptanya hubungan harmoni antara manusia dengan Tuhan Sang Pencipta, manusia dengan manusia dan manusia dengan lingkungan. Konsep tersebut di sejajarkan dengan konsep keseimbangan lain seperti Theologis, sosiologis dan ekologis atau artefact, sociofact dan mentifact. Berdasarkan persamaan tersebut, Mudana berpendapat bahwa Tri Hita Karana merupakan pengetahuan lokal layak diapresiasi.

Ilhaq (2016) melakukan penelitian dengan judul bentuk dan penempatan ornamen pada mesjid Agung Palembang, hasil penelitian dimuat dalam jurnal ekspresi seni Vol. 18 No. 2. Penelitian ini sangat berguna sebagai salah satu data acuan untuk penelitian ini. Pembahasan deskriptif bentuk dan penempatan ornamen pada mesjid Agung Palembang pada penelitian ini melahirkan klasifikasi ornamen pada mesjid Agung Palembang, yakni kelompok ornamen geometris, kelompok ornamen kaligrafi arab dan kelompok ornamen tumbuhan (Ilhaq, 2016: 184). Tampaknya, kelompok ornamen tumbuhan yang paling dominan di mesjid Agung Palembang bahkan terlihat sangat mencolok. 


\section{Pembahasan}

A. Ragam Hias Pada Masjid Agung Palembang

Pengamatan terhadap masjid Agung Palembang, secara fisik dipengaruhi oleh budaya Cina, Arab Eropa dan Nusantara akulturasi tersebut menjadi ciri khas arsitektur bangunannya, sangat menonjol terutama bagian atap yang yang berundak/bertingkat dengan jurai di setiap sisinya. Di samping itu, secara fungsional masjid Agung Palembang sangat kompleks. Tidak hanya sebagai tempat ritual ibadah saja, mamun juga sebagai tempat melaksanakan berbagai kegiatan keagamaan, sosial dan pendidikan seperti yang sudah dijelaskan sebelumnya.

Terkait dengan sumber belajar, semua hal tentang Masjid Agung Palembang tersebut dapat di manfaatkan sebagai sumber belajar yang terdapat di tengah-tengah masyarakat. Selain itu, khususnya materi seni rupa. Masjid Agung Palembang sangat kaya dengan ragam hias, penerapan ragam hias tersebut terdapat di berbagai bidang masjid. Terutama pada bagian bangunan lama penerapan ragam hias mulai dari tiang, mimbar, jendela, pintu hingga atap tidak luput dari penerapan ragam hias dengan berbagai ragam corak, warna dan teknik penerapan.

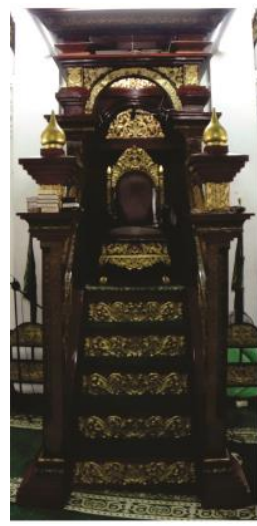

(a)

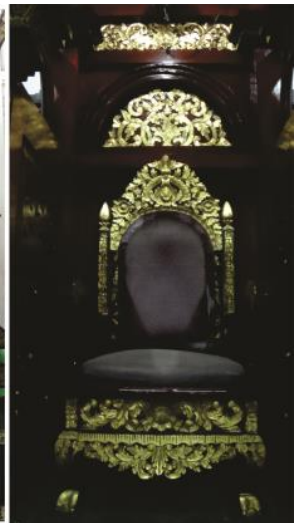

(b)
Gambar 1. (a) Mimbar, (b) Kursi Khatib, (Ilhaq, 2019)

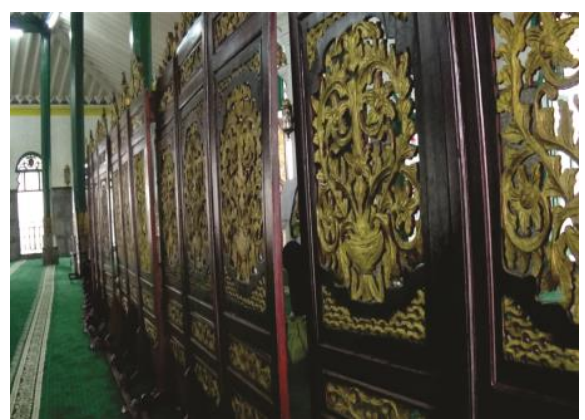

Gambar 2. Pembatas Sholat,

(Ilhaq, 2019)

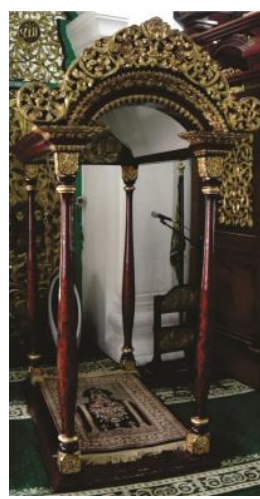

(a)

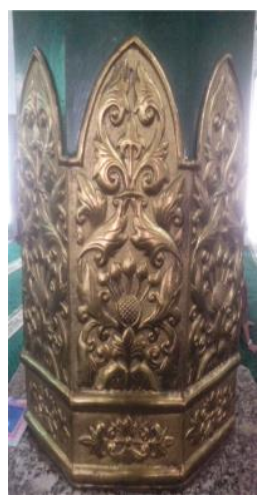

(b)
Gambar 3. (a).Tempat Imam memimpin Sholat (b). Tiang (soko guru) (Ilhaq, 2019)

Berdasarkan beberapa gambar di atas, tampak penerapan ragam hias. menjadi salah satu bagian penting dari Masjid Agung Palembang. Toekio (2000) Menyebutkan Bahwa ragam hias hadir di tengah-tengah kehidupan masyarakat sebagai media ungkap perasaan yang diwujudkan dalam bentuk visual, proses penciptaannya tidak terlepas dari pengaruh lingkungan. Tentu ragam hias sebagai salah satu elemen dari bangunan Masjid Agung Palembang tidak lepas dari kearifan lokal (local genius), baik dari segi teknik pengerjaan, alat dan bahan yang digunakan maupun pemaknaan terhadap ragam hias tersebut.

\section{B. Analisis Kurikulum}

Istilah kurikulum ditafsirkan berbeda oleh pakarpakar sesuai dengan pandangan pakar yang bersangkutan. Menurut Hamalik (2014: 16) Kata kurikulum berasal dari bahasa latin yaitu "curriculae" artinya jarak yang harus ditempuh oleh seorang pelari. Istilah kurikulum lazim digunakan dan menjadi bagian penting dalam dunia pendidikan, kurikulum mengatur aktifitas pembelajaran setiap satuan pendidikan mulai dari isi dan bahan pelajaran hingga cara yang digunakan untuk mencapai tujuan penyelenggaraan pendidikan. Tentunya setiap jenjang satuan pendidikan terutama lembaga pendidikan formal memiliki kurikulum sebagai pengatur arah dan tujuan pelaksanaan pembelajaran.

Berdasarkan kurikulum Program Studi Pendidikan Sendratasik Universitas PGRI Palembang disebutkan bahwa tujuan prodi sendratasik adalah pertama, menghasilkan lulusan pendidikan sendratasik yang unggul, profesional, mampu mengajar dibidang kesenian tingkat SMP dan SMA/SMK. Kedua, menghasilkan karya seni dengan identitas yang berciri Sumatera Selatan. Ketiga, Menghasilkan penelitian, karya di bidang kesenian baik pendidikan maupun non kependidikan. Keempat, meningkatkan pengabdian kepada masyarakat dibidang kesenian (Kurikulum Program Studi Sendratasik,2016).

Setiap kegiatan pembelajaran harus merujuk pada tujuan yang sudah ditentukan tersebut, seperti yang disebutkan oleh Hamalik (2014: 18-19) bahwa. 
"Penyusunan kurikulum bertujuan untuk mewujudkan tujuan pendidikan nasional dengan memperhatikan tahap perkembangan peserta didik dan kesesuaiannya dengan lingkungan, kebutuhan pembangunan nasional, perkembangan ilmu pengetahuan dan teknologi serta kesenian, tentunya sesuai dengan jenis dan jenjang masing- masing satuan pendidikan".

Dalam Rencana Pembelajaran Semester (RPS) mata kuliah Pengetahuan Seni Rupa prodi pendidikan sendratasik juga dideskripsikan bahwa Mata kuliah Pengetahuan Seni Rupa memberikan pemahaman teoritis terhadap pengertian, ruang lingkup dan manfaat seni rupa dalam kehidupan sehari-hari. Disamping itu, melatih mahasiswa untuk terampil, kreatif dan inovatif menciptakan benda-benda dekoratif maupun fungsional mulai dari desain, pemanfaatan bahan dan penggunaan alat. Di samping itu, juga disebutkan bahwa tujuan dari mata kuliah pengetahuan seni rupa agar mahasiswa memiliki kompetensi: (1) wawasan, keterampilan, nilai, dan sikap dalam pengembangan konsep seni rupa, (2) mengetahui permasalahan dan dasar-dasar pembelajaran seni dari sudut pandang seni rupa, (3) serta mampu menerapkan pendekatan-pendekatan dalam upaya menyelesaikan masalah pembelajaran di bidang seni rupa (RPS Pengetahuan Seni Rupa, 2016).

Dipahami, sebagai Program Studi (Prodi) yang berada di bawah naungan Fakultas Keguruan dan Ilmu Pendidikan (FKIP) Universitas PGRI Palembang, tentu kurikulum prodi sendratasik mengacu kepada ilmu kependidikan, dalam hal ini pendidikan seni khususnya pengetahuan seni rupa, sudah jelas bahwa tujuan pembelajaran pengetahuan seni rupa di Prodi Sendratasik, lebih ditekankan pada kemampuan pedagogi mahasiswa untuk mengajar seni rupa di sekolah.

Berdasarkan pembahasan kurikulum program studi pendidikan sendratasik di atas, agaknya cukup relevan apabila ragam hias pada Masjid Agung Palembang menjadi salah satu materi pembelajaran pengetahuan seni rupa. Selanjutnya Toekio (2000) menjelaskan bahwa ragam hias tentu tidak terlepas dari unsur-unsur pendukung terjadinya bentuk visual yang ditampilkan. Terkait dengan itu, unsur visual sangat besar artinya. Elemen pembentuk visual seperti garis, bidang tekstur dan warna ragam hias perlu diperkenalkan kepada mahasiswa melalui pembelajaran pengetahuan seni rupa. Banyak hal yang dapat di pelajari dari visual ragam hias, penerapan ragam hias dengan teknik gradasi menjadi salah satu pilihan, keterbatasan waktu, kemampuan serta karakter mahasiswa program studi pendidikan sendratasik Universitas PGRI Palembang merupakan alasan pilihan penerapan teknik gradasi tersebut.

\section{Ragam Hias Sebagai Sumber Belajar}

Cakupan sumber belajar sangat luas, berbagai penjelasan dan pendapat mengenai sumber belajar telah banyak dikemukakan oleh para ahli, namun Association for Educational Communication and Technology (AECT, 1977) telah mengelompokkan sumber belajar pada pesan, orang, bahan, alat, prosedur, dan lingkungan, berikut fungsi utamanya untuk mempermudah kegiatan belajar (facilitating learning) dan meningkatkan kinerja (improving performance) (dalam Sitepu, 2014 :19). Agaknya komponen tersebut dianggap relevan hingga sekarang sebagai dasar rujukan untuk mengidentifikasi pengertian sumber belajar.

Berdasarkan klasifikasi sumber belajar dalam $A E C T$, selanjutnya Seel dan Richey (dalam Abdullah, 2012) menjelaskan bahwa Pesan adalah informasi yang disampaikan dan berkaitan dengan konteks pembelajaran yang akan dikelola dan direkonstruksikan kembali oleh pebelajar. Orang, adalah penyaji maupun penyalur pesan. Bahan, merupakan kelompok perangkat lunak (software) yang akan disalurkan menggunakan alat tertentu, dapat berupa teks tertulis, cetak, rekaman yang dapat digunakan untuk belajar. Sedangkan alat adalah perangkat keras (hardware) yang digunakan untuk menyajikan bahan pembelajaran seperti komputer, kamera, dan televisi. Selanjutnya prosedur merupakan teknik atau cara yang digunakan dalam kegiatan pembelajaran untuk mencapai tujuan pembelajaran. Kemudian lingkungan merupakan tempat atau latar dimana saja seseorang melakukan aktifitas belajar sebagai proses perubahan tingkah laku, maka dikategorikan sebagai sumber belajar.

Merujuk pada penjelasan tentang sumber belajar di atas Sitepu (2014: 18) merumuskan sumber belajar sebagai suatu yang dapat dipergunakan untuk mendukung dan memudahkan terjadinya proses belajar, dengan kata lain, dapat dipahami bahwa sumber belajar merupakan sarana bagi pebelajar untuk mencapai tujuan pembelajaran. Jadi sumber belajar harus fungsional dan mengandung kebermaknaan agar rekonstruksi informasi bisa dikelola dengan baik.

Hakikatnya, di tengah-tengah masyarakat terdapat aneka sumber belajar yang dapat dimanfaatkan oleh anggota masyarakat secara individual atau bersama-sama dalam kelompok (Sitepu,2014:36). Salah satu jenis sumber belajar yang dibuat bukan untuk keperluan belajar namun dapat dimanfaatkan untuk keperluan belajar, seperti Masjid Agung Palembang, salah satu bangunan yang dipandang cukup fenomenal di Palembang, berbagai informasi terkait sejarah peradaban, kondisi ekonomi, politik, keadaan sosial masyarakat pada masa lalu dapat dipelajari. Di samping fungsi utamanya sebagai tempat ibadah, masjid Agung Palembang juga berfungsi sebagai tempat pendidikan dan berbagai aktifitas kegiatan sosial.

Sementara itu, kemegahan fisik bangunan Masjid Agung Palembang dihiasi dengan bebagai bentuk ragam hias, teknik penerapan dan penempatan yang bervariasi tidak hanya sekedar ornamentasi keindahan visual, namun ragam hias tersebut juga menunjukkan kebesaran Kesultanan Palembang Darussalam pada masa lalu.

D. Pelaksanaan Pembelajaran Seni Rupa dengan materi ragam hias

1. Penjelasan materi ragam hias.

Tahap awal merupakan pengantar materi ragam hias, serta sosialisasi tugas yang akan dikerjakan mahasiswa yaitu penggarapan ragam hias pada masjid Agung 
Palembang dengan teknik gradasi. Penjelasan tahap pengerjaan teknik gradasi maupun persiapan alat dan bahan yang dibutuhkan. Kemudian menentukan objek ragam hias yang akan di garap oleh masing-masing mahasiswa.

Tahap ini juga sebagai observasi, iventarisir pengetahuan dan kemampuan mahasiswa dalam menggarap ragam hias. Selain itu, melihat karakteristik mahasiswa secara umum.

Hamalik (2014: 18) menegaskan bahwa kegiatankegiatan kurikulum tidak terbatas dalam ruang kelas saja, melainkan mencakup juga kegiatan-kegiatan di luar kelas. Berdasarkan pendapat tersebut, mahasiswa di instruksikan untuk datang langsung ke masjid Agung Palembang menentukan sendiri objek ragam hias yang akan digarap.

Selama proses ini pada dasarnya telah terjadi interaksi dengan objek yang diamati, sebagai tahap eksplorasi sebelum menggarap suatu karya seni rupa. Mengenali dan mempelajari objek garapan karya seni sangat penting, sebab interpretasi sangat dipengaruhi oleh latar belakang pengetahuan dan penghayatan interpretant.

2. Proses Seleksi Foto Objek Ragam Hias

Objek foto ragam hias yang di dapatkan oleh mahasiswa di Masjid Agung Palembang perlu di pertimbangan tingkat kesulitan serta kelayakan ragam hias tersebut, foto ragam hias yang dianggap layak disarankan untuk diteruskan pada tahap desain.

Masukan maupun saran perlu diberikan terkait dengan desain, anjuran untuk melakukan rekonstruksi bentuk desain akan menjadi pertimbangan penting pada saat dilakukan evaluasi.

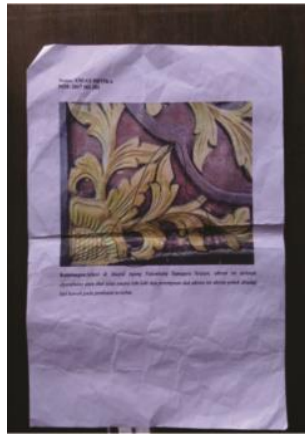

(a)

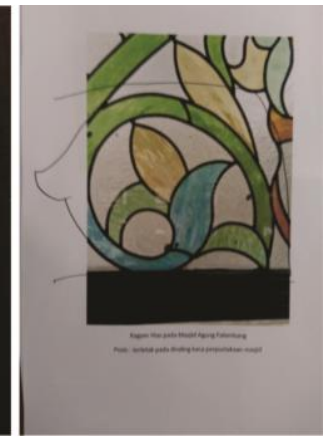

(b)
Gambar 4. Hasil foto ragam hias di masjid Agung Palembang,

(a) Anggi Devika,

(b) Anindya Laila Sari,

(Foto: Rio ,2019)

\section{Proses Membuat Desain}

Pembuatan desain kerja berdasarkan foto ragam hias yang terdapat pada Masjid Agung Palembang. Disarankan melakukan pengayaan atau pengembangan bentuk desain ragam hias, baik dengan teknik transformasi, teknik stilisasi maupun deformasi sebagai bagian kreatifitas.

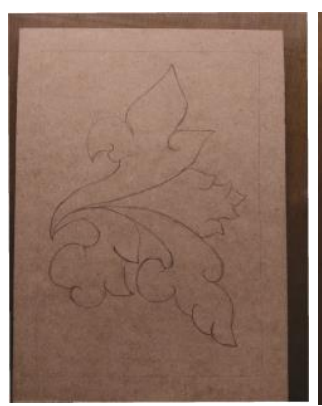

(a)

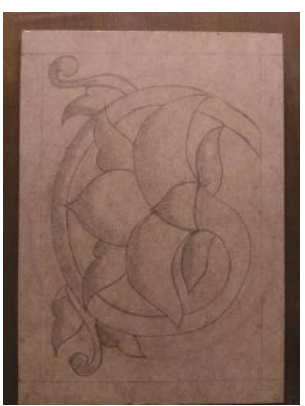

(b)
Gambar 5. Desain ragam hias
(a)Anggi,
(b) Anindya

(Foto: Rio ,2019)

\section{Proses Pewarnaan Teknik Gradasi}

Pada proses ini, merupakan suatu pengalaman mengolah warna, teknik mencampur warna serta mengetahui unsur pembentuk warna. Tahap ini harus dilakukan dengan sabar, hati-hati dan membutuhkan konsentrasi yang baik.

Media kerja yang digunakan adalah kertas karton tebal 300 gsm dengan ukuran $23 \mathrm{~cm}$ x $33 \mathrm{~cm}$. Sementara alat yang digunakan adalah kuas lukis, disarankan menggunakan kuas nomor 2 atau memilih kuas sesuai dengan kebutuhan, sementara bahan yang digunakan cat tembok warna putih, sari warna biru, merah dan kuning dan wadah penampung cat (valet).

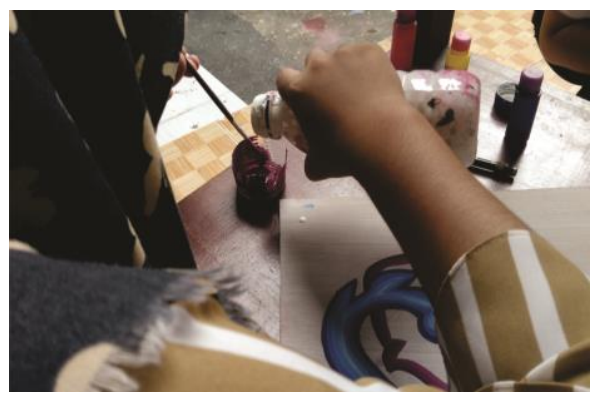

Gambar 6. Proses membuat (mencampur) warna Foto: Rio ,2019)

5. Hasil

Berikut karya ragam hias teknik gradasi dengan ide garapan ragam hias pada masjid Agung Palembang.

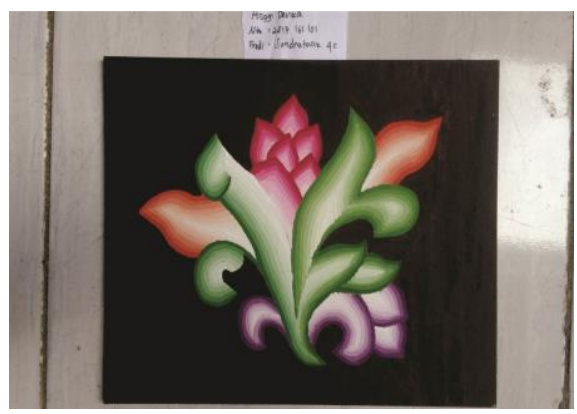

Gambar 7. Karya : Anggi Devika

(Deformasi Bentuk ragam hias pada Masjid Agung

Palembang dengan teknik gradasi) (Foto: Rio, 2019) 


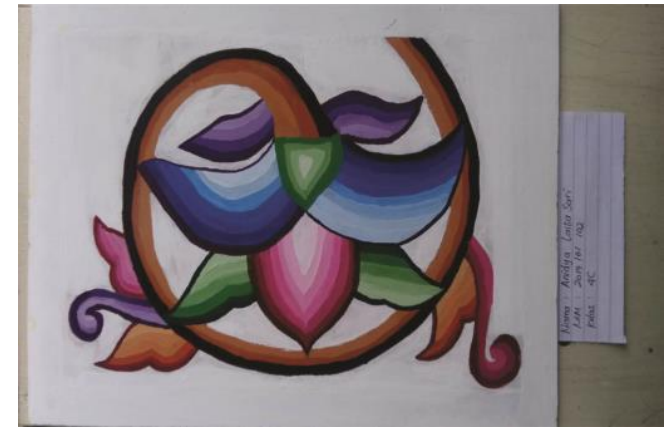

Gambar 8. Karya: Anindya Laila Sari

(Stilisasi bentuk ragam hias pada Masjid Agung Palembang dengan teknik gradasi)

(Foto: Rio ,2019)

\section{Kesimpulan}

Analisis kurikulum menunjukkan bahwa tujuan pembelajaran pengetahuan seni rupa di Prodi Sendratasik lebih ditekankan pada kemampuan pedagogi mahasiswa untuk mengajar seni rupa di sekolah. Seperti yang telah diuraikan sebelumnya, bahwa tahap pelaksanaan pembelajaran pengetahuan seni rupa dengan materi ajar ragam hias pada Masjid Agung Palembang, mulai dari tahap penjelasan materi ragam hias, proses seleksi objek ragam hias, proses pembuatan desain, proses pewarnaan, finishing dan tahap evaluasi karya. Setiap proses tersebut merupakan informasi dan wawasan baru bagi mahasiswa, selain itu mahasiswa juga memiliki keterampilan me-rekonstruksi bentuk ragam hias dengan teknik gradasi. Seperti yang disebutkan oleh Sudira (2010: 78) bahwa proses kreasi seni memiliki beberapa tahapan yakni pengamatan/mengamati, merasakan, berfikir, kemudian muncul sebuah ide dan gagasan kreatifitas dan ekspresi. Selanjutnya Husni dan Wandi (2018:143) menegaskan bahwa untuk penampilan kesenian ada tiga unsur yang berperan, yaitu bakat (talent), keterampilan (skill), sarana atau media. Rangkaian proses tersebut merupakan satu kesatuan yang membentuk mahasiswa mengembangkan kepekaan estetis, inovatif dan memiliki daya kritis terhadap lingkungan.

\section{Daftar Pustaka}

Abdullah, Ramli. 2012. Pembelajaran Berbasis Pemanfaatan Sumber Belajar. Jurnal ilmiah Didaktika, Volume XII (2). Banda Aceh

Ilhaq, Muhsin. 2016. Bentuk dan Penempatan Ornamen pada Mesjid Agung Palembang. Jurnal Ekspresi Seni, Volume 18 (2). Padangpanjang

Mudana, I Wayan. 2007. Pengetahuan Lokal dalam Epistemologi Relasional: Kajian Filsafat Kebudayaan. Jurnal Seni Budaya Mudra, Volume 21(2). Bali

Mubarat, Husni dan Iswandi. 2018. Kajian Estetika Seni Ukir Kayu Khas Palembang pada Al- Qur'an AlAkbar (Laporan Penelitian). Universitas Indo Global Mandiri (UIGM). Palembang
.2018 .

Aspek-aspek

Estetika Ukiran Kayu Khas Palembang Pada AlQuran Al Akbar. Jurnal Ekspresi Seni, Vol 20 (2). Padangpanjang.

Nawiyanto, Endrayadi. 2016. Kesultanan Palembang Darussalam: Sejarah dan Warisan Budayanya. Jember University Press dan Penerbit Tarutama Nusantara. Jember

Rosyada, Dede. 2013. Urgensi Media Untuk Sukses Proses Pembelajaran (kata sambutan). Dalam: Arsyad. 2014. Media Pembelajaran (edisi revisi). PT Raja Grafindo Persada. Jakarta.

Rohidi. Tjetjep Rohendi. 2011. Metodologi Penelitian Seni. Cipta Prima Nusantara Semarang. Semarang

Reswari, Ardhani. 2015. Sejarah Masjid Agung Palembang. Kompasiana. https://www.kompasiana.com/ardhani-reswari/

Sitepu, B.P. 2014. Pengembangan Sumber Belajar. PT Raja Grafindo Persada. Jakarta.

Sudira, Made Bambang Oka. 2010. Ilmu Seni Teori dan Praktik. Inti Prima. Jakarta 